\title{
Implementation of Mobile Virtual Colored Overlay for People with Scotopic Sensitivity Syndrome
}

\author{
Jang Young Gun ${ }^{\dagger}$
}

\begin{abstract}
A film colored overlay has been used as an assistive device for dyslexics, Recently, several virtual colored overlays which can be used in computer were developed. But mobile virtual overlay has not been developed yet.

In this paper, I implemented a mobile overlay application which is based android operating system and displays a colored overlay of screen all the time while user can freely interact with rest of apps in normal manner by using root window and service. A method is presented to determine the source color of a virtual overlays by estimating alpha value of alpha blending algorithm through measurement of the chromaticity and transmissivity of film overlays and I implemented all colors which are presented by using Intuitive Overlays. Test results of the developed virtual overlay show that all colors of the overlays are almost identical to the colors of Intuitive Overlay by using the chroma meter CS-200A.
\end{abstract}

Keywords : Scotopic Sensitivity Syndrome, Virtual Colored Overlay, Mobile Environments, Alpha Value Estimation, Control An Overlapped App

\section{광과민성 증후군자를 위한 태블릿 $\mathrm{PC}$ 와 스마트폰 용 가상 색 오버레이 구현}

장 영 건 ${ }^{+}$

요 약

\begin{abstract}
색 오버레이는 광과민성 증후군의 증세를 완화시키는 보조도구로 사용되어 왔다. 최근에 컴퓨터에서 사용할 수 있는 몇 종의 가상 색 오버 레이가 개발되었으나, 모바일 환경에서 사용할 수 있는 것은 발표된 바 없다.

본 논문에서는 안드로이드의 최상위 윈도우를 활용하여 가상 색 오버레이를 이동시키지 않고 겹쳐진 앱이나 화면을 제어할 수 있는 모바일 용 가상 색 오버레이를 구현하였다. 분광측색계를 이용하여 필름 오버레이의 색도 정보와 투과율을 측정하여 가상 색 오버레이에 적용할 색상 정보를 추정하는 방법을 제안하였고, Intuitive Overlays에서 표현하는 모든 색상을 구현하였다. 시험 결과 기존의 필름 오버레이를 사용한 것과 동일한 효과를 얻었다.
\end{abstract}

키워드 : 광과민성 증후군, 가상 색 오버레이, 모바일 환경, 색상 정보 추정, 겹쳐진 앱 제어

\section{1. 서 론}

2010년 12월 방송통신위원회에서 한국형 웹 접근성 지침 2.0[1]을 표준으로 제정하였고, 2011년 9월에는 행정안전부에 서 모바일 애플리케이션 접근성 지침[2]을 고시로 발표하였 다. 이 지침들에는 공통적으로 광과민성 발작 장애에 대한 지침이 추가되었고, 이 증상을 갖는 사용자들이 쉽게 접근 할 수 있는 웹 콘텐츠를 구축하는데 필요한 방법들을 소개

\footnotetext{
† 정 회 원: 청주대학교 컴퓨터정보공학과 교수 논문접수: 2012년 10월 30 일

수 정 일 : 1 차 2012 년 12 월 20 일

심사완료 : 2013년 1월 14일

* Corresponding Author: Jang Young Gun(ygjang@cju.ac.kr)
}

하고, 이를 의무화하고 있다. 그러나 검사항목에는 초당 3-50 Hz 주기로 깜박이거나 번쩍이는 콘텐츠를 제공하지 않 는 것으로 한정하고 있어, 시각적 스트레스, 시각적 편두통 자와 같은 비교적 경증의 광과민성 증후군자에 대한 고려는 하지 않고 있다. 광과민성 증후군의 증상은 Fig. 1과 같이 선들의 번짐, 선들이 떠다니는 현상, 선들이 지그재그로 엇 갈리는 현상과 같은 시각적 왜곡과 어지럼증과 메스꺼움과 같은 시각적 불편으로 분류할 수 있으며, 읽기장애를 일으 켜, 학습장애로 발전하게 되는 문제를 갖고 있다. 광과민성 발작과 같은 광과민성 증후군의 증상들은 디스플레이 장치 가 작을 때 더 심하게 나타나며, 따라서 스마트 폰이나 태 블릿 $\mathrm{PC}$ 와 같이 작은 디스플레이 장치를 갖는 모바일기기 
에서 광과민성 증후군자에 대한 접근성 문제가 더욱 심각하 게 나타날 수 있다. 최근 유튜브가 국내 인터넷 소비자 1023 명을 대상으로 한 '모바일 동영상 이용행태 분석'에 따르면 '커뮤니케이션(89.9분)' ‘음악감상(79.8분)' ‘방송 콘텐트 시청 (76.4분)' 순으로 이용시간이 많았으며, 데스크톱 $\mathrm{PC}$ 에선 하 루 평균 6.1 분 정도만 읽히던 전자책(e-Book)의 비중이 모 바일에서는 하루 50분으로 대폭 늘어났다[3]. 미국의 캘리포 니아에서는 종이로 만든 교과서 대신 태블릿 $\mathrm{PC}$ 의 일종인 아이패드를 이용한 전자교과서의 사용이 권장되고 있으며, 이러한 추세는 앞으로 더욱 가속화될 전망이다.

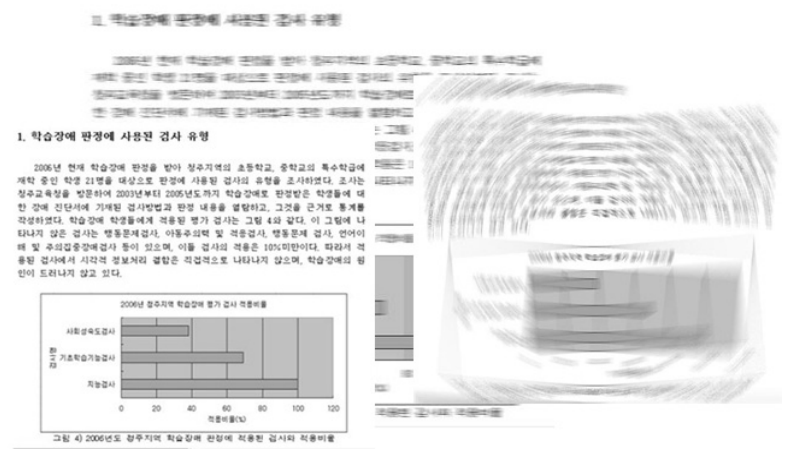

Fig. 1. Visual phenomena of people with Scotopic Sensitivity Syndrome to electronic documents

1958년 난독증 아이가 색 카드에 적힌 글자만을 읽을 수 있다는 것이 최초로 보고되었다. 뉴질랜드의 교사인 Olive Mears는 문서에 대한 아이들의 인식과 읽기 장애가 출판물 의 특성에 영향을 받으며, 문서의 크기를 줄이고, 색 종이를 사용하고, 대조를 줄이면 장애를 줄일 수 있다고 보고하였다 [4]. 이 증상을 완화시키는데 색 오버레이가 효과적이라는 것 을 처음 보고한 사람은 미국의 임상심리학자인 H. Irlen이고, 광과민성 증후군이라는 용어를 처음으로 사용하였다[5]. 이후 이 증상을 두 사람의 이름을 따서 Mears-Irlen 증후군이라고 부르기도 한다. 이 증후군은 뇌의 거대세포의 결함에 의하여 발생되는 것으로 밝혀지고 있다. 뇌의 거대세포(magnocell)의 결함과 관련된 시각적 문제를 갖고 있는 사람은 두정 골 피 질 영역의 기능과 관련된 시각적으로 주목할 방향을 결정하 고, 제어하는 능력이 떨어지며, 결과적으로 안구운동 능력과 시각적 탐색 능력이 떨어지는 경향이 있다. 색 정보의 경로 는 주의와 안구 운동이 관여하는 곳에 강하게 연결되어 있으 며, 색 자극이 뇌의 시각적 정보처리를 담당하는 거대세포에 영향을 미치며, 특히 광과민성 증후군자에 있어 해당 거대세 포의 이상이 있으면 그 영향이 크게 나타난다. 얼렌(Irlen)은 이 원리를 이용하여 필름형 색 오버레이를 처음으로 발명하 여 광과민성 증후군자에게 1980년부터 임상적으로 적용하였 으며, 그 효과가 입증되었다. 색 자극은 대상자에 따라 다르 며, 특정한 색 자극에서 그 효과가 크게 나타난다.

국내에서 대전지역의 학생 1,177 명을 대상으로 주의력결핍, 과잉행동과 시지각능력을 설문조사한 연구[6]에 의하면 전체 학생의 $18.6 \%$ 가 주의력결핍.과잉행동 의심군으로 분류되며,
주의력결핍·과잉행동은 시지각 영역1(독서능력 및 독서할 때 불편한 증상) 및 시지각영역2(광과민성, 주변인식능력, 입체 감)와 유의한 상관성을 갖는다고 하여, 광과민성 증후군 및 유사증상을 갖는 사람들의 비율이 적지 않음을 알 수 있다.

$\mathrm{PC}$ 에서 사용할 수 있는 가상 색 오버레이는 Virtual Reading Ruler[7]라는 제품이 세계에서 최초로 발표되었고, 국내에서도 2008년 처음으로 개발된 바 있다[8]. 그러나 웹 검색에 의하면 스마트 폰이나, 태블릿 $\mathrm{PC}$ 에서 광과민성 증 후군자를 위하여 정보통신 접근성을 향상시키는 앱은 세계 적으로 발표된 바 없다. 따라서 광과민성 발작과 같은 광과 민성 증후군자들을 위한 스마트폰 및 태블릿 $\mathrm{PC}$ 사용자의 전자문서 접근성을 제고할 수 있는 보조도구의 개발이 시급 히 요청되고 있다.

본 논문에서는 광과민성 증후군자에게 유효하다고 알려진 색 자극을 체계적으로 제공하며, 대상자가 자신에게 유효한 색 자극을 쉽게 선택할 수 있는 안드로이드 운영체계를 사 용하는 스마트 폰과 태블릿 $\mathrm{PC}$ 에서 동작하는 색 자극기인 가상 색 오버레이를 구현하였다.

\section{2. 가상 색 오버레이의 색 정보 추정}

본 논문의 가상 색 오버레이의 색 견본은 Wilkins[9]의 필름 색 오버레이인 Intuitive Overlays[10]를 참조하여 실제 제품을 측정하여 결정하였다. Intuitive Overlays의 색상정보 를 Fig. 2에 $\mathrm{CIE} \mathrm{Lu}^{\prime} \mathrm{v}^{\prime}$ 색좌표로 표시하였다. 가상 색 오버 레이는 Intuitive Overlay의 색상정보를 가진 안드로이드 운 영체제에서 동작하는 애플리케이션 프로그램으로서, 알파 블렌딩 기법을 이용하여 투명한 오버레이 효과를 구현하였 다. 알파 블렌딩을 이용하여 투명한 오버레이 효과를 나타 내기 위해서는 적절한 $\mathrm{RGB}$ 색상 정보가 필요하며, 다음과 같은 과정을 통해 필요한 $\mathrm{RGB}$ 값을 구하였다.

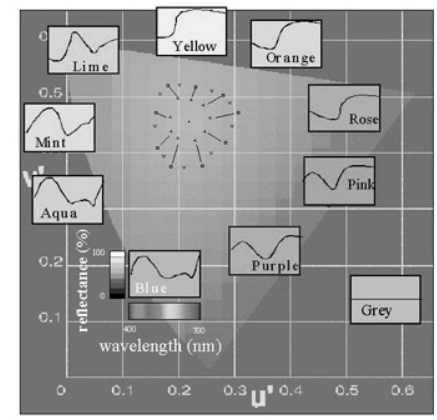

Fig. 2. Chromaticity(u',v') of Intuitive Overlays

분광측색계를 이용하여 Wilkins의 Intuitive Overlays의 단일 색, 단일 색 중첩, 인접 색 중첩의 색 정보와 투과율을 측정하였다. 분광측색계는 Konica Minolta사의 CM-3600d를 사용하였다. CM3600d의 측정파장 범위는 360-740nm로 가 시광선 영역을 모두 측정할 수 있고, 측정파장 간격은 $10 \mathrm{~nm}$ 이며, 재현성은 표준편차 $0.1 \%$ 이내이다. 측정 방법은 장치를 
보정한 다음, 오버레이 필름을 장치의 수광부 입구에 위치 시키고, 좀 더 우툴두툴한 면(시각 면)으로 광을 투과시켜 오버레이의 색 $\left(\mathrm{CIE}-\mathrm{L} * \mathrm{u}^{\prime} \mathrm{v}^{\prime}\right)$ 과 투과율을 측정하였다.

측정된 색의 값을 $\mathrm{CIE}-\mathrm{L} * \mathrm{u}^{\prime} \mathrm{v}^{\prime} \rightarrow \mathrm{XYZ} \rightarrow \mathrm{RGB}$ 로의 변환[11] 과정을 거쳐 $\mathrm{RGB}$ 색상 값으로 변환하였다. 단, 밝기 정보는 실제 구현되는 장치에 따라 변하므로, $\mathrm{Y}$ 값이 1 일 때를 기 준으로 변환하였다. XYZ좌표계에서 RGB좌표계로 변환할 때, RGB좌표 중 255를 넘는 값이 일부 색상에서 발생하였 다. 이 경우 $\mathrm{RGB}$ 값의 최대치로 전체 $\mathrm{RGB}$ 색상을 스케일링 하는 방법과 255 값을 초과하는 만큼 전체 $\mathrm{RGB}$ 값을 줄여주 는 방법[11]이 있다. 두 방법으로 산출된 $\mathrm{RGB}$ 값을 역변환하 여 $\mathrm{Lu}^{\prime} \mathrm{v}^{\prime}$ 값을 산출한 결과, 최대값 스케일링 방법이 측정한 $\mathrm{Lu}^{\prime} \mathrm{v}^{\prime}$ 값에 더 근사한 값을 얻을 수 있었다. 본 논문에서는 최대값 스케일링 방법을 사용하였다. RGB 색상은 Wilkins 의 Intuitive Overlays의 RGB 색상으로 가상 색 오버레이에 알파 블렌딩을 적용하여 오버레이 효과를 구현하였을 때 나 타날 색상 정보이다. 실제 필요한 RGB 정보는 알파 블렌딩 을 적용하기 전의 원(Source) 색상 정보가 필요하며, 이는 알파 블렌딩 알고리즘을 역변환하여 구하였다.

$$
\mathrm{O}=\mathrm{a} * \mathrm{~S}+(1-\mathrm{a}) * \mathrm{~B}
$$

식 (1)은 알파 블렌딩 알고리즘으로써, $\mathrm{S}$ 는 전경이 되는 원(source)색, $\mathrm{B}$ 는 배경(background)색, $\mathrm{a}$ 는 투명도 (transparency)를 나타내며, 투명도는 $0.0 \sim 1.0$ 사이의 숫자 로 표현된다. 0 은 투명, 1 은 불투명을 나타내며, 0 에 가까울 수록 점점 투명하며, 1 에 가까울수록 점점 불투명하게 된다. $\mathrm{O}$ 는 결과색(Output)을 나타낸다.

식 (2)는 원 색상 정보 $\mathrm{S}$ 를 구하기 위한 것으로 식 (1)에 서 유도된다.

$$
\mathrm{S}=(\mathrm{O}-(1-\mathrm{a}) * \mathrm{~B}) / \mathrm{a}
$$

식 (2)를 이용하여 R G B 각각의 원 색상 $\mathrm{S}_{\mathrm{r}}, \mathrm{S}_{\mathrm{g}}, \mathrm{S}_{\mathrm{b}}$ 를 식 (3)과 같이 구할 수 있다.

$$
\begin{aligned}
& \mathrm{S}_{\mathrm{r}}=\left(\mathrm{Or}-(1-\mathrm{a}) * \mathrm{~B}_{\mathrm{r}}\right) / \mathrm{a} \\
& \mathrm{S}_{\mathrm{g}}=\left(\mathrm{Og}-(1-\mathrm{a}) * \mathrm{~B}_{\mathrm{g}}\right) / \mathrm{a} \\
& \mathrm{S}_{\mathrm{b}}=\left(\mathrm{Ob}-(1-\mathrm{a}) * \mathrm{~B}_{\mathrm{b}}\right) / \mathrm{a}
\end{aligned}
$$

원 색상 정보 $\mathrm{S}$ 를 구하기 위해 $\mathrm{B}$ 의 값은 백색 배경을 나 타내는 $0 \mathrm{xFF}$ 를 적용하였다. $\mathrm{a}$ 값은 0 에 가까울수록 투명함 을 나타내므로 분광측색계를 이용하여 측정한 투과율 $\mathrm{t}$ 와는 역관계를 갖는다. 각 색상에 적용할 a 값은 식 (4)를 이용하 여 추정하였다.

$$
a=(100-t) / 100
$$

원 색상 $\mathrm{S}_{\mathrm{r}}, \mathrm{S}_{\mathrm{g}}, \mathrm{S}_{\mathrm{b}}$ 중에 하나의 계산 결과가 음수(-)인 경 우는 색을 표현할 수 없으므로 $0 \mathrm{x} 00$ 으로 대치하고, 나머지 색 요소에 음수 값의 절대 값의 반을 더하였다. 이 방법은 시각 에 의존하여 해당 색의 필름 오버레이를 컴퓨터 백색배경 화

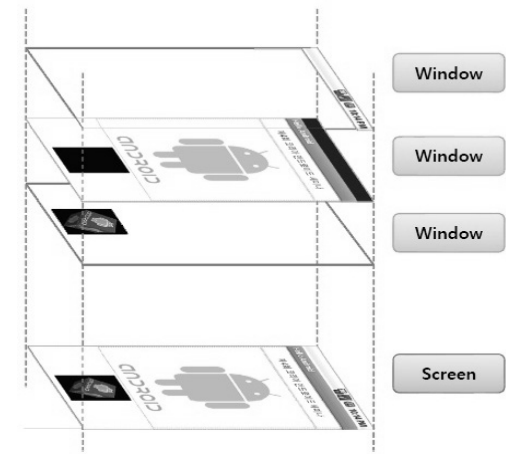

Fig. 3. Example of Android screen composed by multiple windows

면에 겹쳐 놓았을 때와 유사한 색을 고르는 과정에서 실험적 으로 선택한 방법이다. 예를 들어, $\mathrm{S}_{\mathrm{r}}$ 값이 -74 일 경우 $\mathrm{S}_{\mathrm{g}}$ 와 $\mathrm{S}_{\mathrm{b}}$ 값을 구할 때 74 의 절대 값을 2 로 나누어 각각에 더하여 결과 값을 산출하였다. 색을 표현하는데 있어, RGB좌표계가 선형적이지는 않다. 그럼에도 불구하고, $\mathrm{S}_{\mathrm{r}}$ 값이 -74 라는 것 은 $\mathrm{R}$ 성분이 74 만큼 적어야 한다는 것을 의미하는데, $\mathrm{R}$ 성분 의 최소 표현 값은 0 이므로 74 만큼 적음을 표현할 수 없다. 따라서 다른 성분, 즉 $\mathrm{G}, \mathrm{B}$ 성분인 $\mathrm{S}_{\mathrm{g}}, \mathrm{S}_{\mathrm{b}}$ 값을 $74 / 2$ 만큼 증 가시킴으로써 비슷한 효과가 나타나도록 하였다.

구현된 가상 색 오버레이는 기존의 가상 색 오버레이에 비 하여 광학적 특성이 보다 필름 색 오버레이와 유사하게 되었 다. Table 1 과 같이 10 가지의 단일 색과 단일 색의 중첩에 의 한 10 가지 색상과 인접 색의 중첩을 통한 9 가지의 색상을 사 용하여 단일 색만을 사용하는 기존 가상 오버레이보다 오버레 이 색상의 선택에 있어 좀 더 세밀한 선택이 가능하며, Wilkins의 Intuitive Overlays가 제공하는 모든 색을 만족한다.

Table 1. Implemented Colors of the Virtual Overlays

\begin{tabular}{|c|c|c|}
\hline Single color & Single color overlapped & Neighbor color overlapped \\
\hline Yellow & Double strength yellow & Yellow-orange overlapped \\
\hline Orange & Double strength orange & Orange-rose overlapped \\
\hline Rose & Double strength rose & Rose-pink overlapped \\
\hline Pink & Double strength pink & Pink-purple overlapped \\
\hline Purple & Double strength purple & Purple-blue overlapped \\
\hline Blue & Double strength blue & Blue-aqua overlapped \\
\hline Aqua & Double strength aqua & Aqua-mint overlapped \\
\hline Mint & Double strength mint & Mint-lime overlapped \\
\hline Lime & Double strength lime & Lime-yellow overlapped \\
\hline Grey & Double strength grey & \\
\hline
\end{tabular}

\section{3. 설계 및 구현}

안드로이드 운영체계에서 가상 색 오버레이의 운용 요구 사항은 첫째, 초기에 선택된 오버레이의 색상은 항상 어떤 화면에서도 공통적으로 작동하여야 하며, 둘째 가상 색 오 버레이는 시각적 효과를 제외하고는 적용 대상 스마트폰이 나 태블릿 $\mathrm{PC}$ 에서 동작하는 모든 화면과 앱의 사용자 인터 페이스에 영향을 주어서는 안되며, 셋째 상황에 따라 선택 된 색상을 변경할 수 있어야 한다. 
윈도우즈 운영체제와 달리 안드로이드 운영체계에는 포그 라운드(foreground) 애플리케이션이 하나이며, 해당 애플리케 이션의 화면 상태는 상태줄을 제외한 전체 스크린을 차지한 다. 사용자가 애플리케이션을 실행시키면 포그라운드에서 실 행되며, 사용자는 다른 애플리케이션을 호출하거나, 같은 애 플리케이션 내의 다른 화면을 호출할 수 있다[12]. 이 모든 프로그램과 화면은 시스템의 액티비티 매니저에 의하여 애플 리케이션 스택에 저장된다. 가상 색 오버레이는 어떤 화면이 나 애플리케이션의 실행중에서도 지속적으로 화면에 나타나 야 하므로 포그라운드 작업을 필수적으로 사용하는 액티비티 로 구현할 수 없다. 서비스는 사용자와의 직접적인 상호작용 없이 배경에서 실행되는 작업이다. 따라서 가상 색 오버레이 를 서비스로 구현하면 화면이나 애플리케이션의 사용자 인 터페이스에 영향을 주지 않고 작동시킬 수 있다.

본 연구에서는 항상 작동하면서 현재 작동되는 애플리케 이션의 상호작용에 영향을 주지 않기 위하여 서비스를 이용 하였고, 스크린에 사용되는 최상위 윈도우에 가상 색 오버 레이를 구현하였다. 가상 색 오버레이 서비스를 실행하거나 중지시키는 기능은 액티비티로 구현하였다. 최초로 이 애플 리케이션을 사용할 때는 자신에게 적합한 색 선택을 한 후 에 그 색이 구현된 오버레이 서비스를 사용하여 작동시켜야 한다. 안드로이드는 다중의 윈도우를 허용한다. 안드로이드 에서 스크린에 나타나는 윈도우가 어떻게 표현되는지를 Fig. 3에 표시하였다.

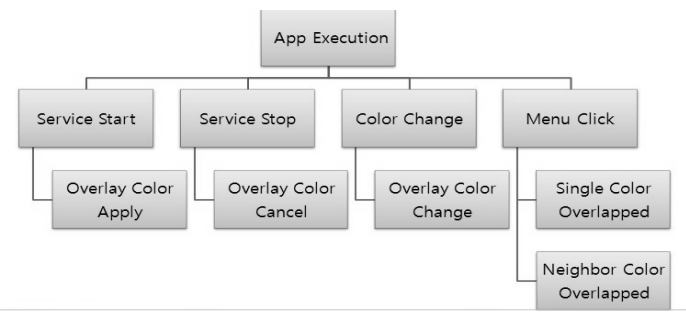

Fig. 4. Functional configuration of virtual overlays App

그림에 나타난 것처럼 백그라운드 서비스를 통하여 최상 위 윈도우에 오버레이를 작동시키면, 사용되는 화면이나 앱 에 관계없이 항상 오버레이가 스크린에 나타난다. 생성된 오버레이를 최상위 윈도우에 넣으면서, 사용자의 터치를 오 버레이를 통해 보이는 화면에 전달하며, 오버레이를 투명하 게 유지하기 위하여 Source 1 과 같이 윈도우매니저의 레이 아웃 매개변수를 설정해 주고, addview메소드를 통하여 오 버레이 뷰를 윈도우에 등록시켜야 한다. addview메소드는 후에 manifest와 서비스에서 허가(permission)을 거쳐야 한 다. 백그라운드 서비스를 사용할 경우 적용되는 스마트 폰 이나 태블릿 $\mathrm{PC}$ 의 메모리의 용량이 구동되는 애플리케이션 의 요구에 비하여 충분하지 못할 때, 운용체제에서 서비스 를 강제 종료시킬 수 있다. 이를 방지하기 위해서는 포그라 운드 서비스를 사용하여야 한다. 포그라운드 서비스에서 현 재 작동중임을 Notification(안드로이드 화면 상단의 상태바) 을 통해 표시해 주면, 사용자가 해당 Service가 현재 작동중 임을 확인할 수 있고, 필요한 경우 운용체제에서 명시적으
로 종료 할 수 있도록 보장한다. 포그라운드 서비스를 시작 하는 방법은, Service 클래스의 내부 메소드인 start Foreground, stopForeground를 사용한다.

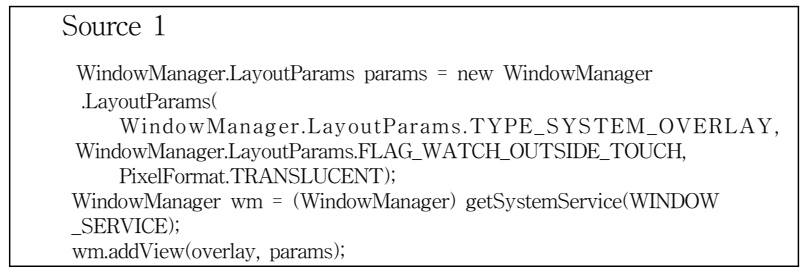

본 논문에서 구현한 가상 색 오버레이 앱의 기능적 구성 도는 Fig. 4와 같다. 기본 색의 선택을 위해서는 color change에서 색상을 변경하며, 색의 중첩이 필요한 경우 메뉴 를 클릭하여 단일 색 중첩이나, 인근 색 중첩을 이용할 수 있다. 색의 선택이 끝나면 서비스 시작(service start)를 눌러 해당 색 오버레이를 백그라운드 애플리케이션에 할당한다.

\section{4. 시험 및 결과}

구현된 가상 색 오버레이 색도의 타당성 검증을 위하여 디스플레이장치의 백색 배경 화면에 가상 색 오버레이를 적 용한 것에 대한 색도 측정 결과 값과 분광측색계를 사용하 여 필름 색 오버레이에 광을 투과시켜 얻은 색상 값을 비교 하였다. 색도 측정은 Konica Minolta사의 CS-200란 휴대용 색도계(Chroma meter)를 사용하였고, 투과광 측정은 Konica Minolta사의 CM-3600d를 사용하였다. 사용된 스마 트폰은 소니사의 엑스페리아 아크이며, 태블릿 $\mathrm{PC}$ 는 삼성전 자의 갤럭시 탭 10.1이다. CS-200은 밝기와 색도를 측정할 수 있으며, 온도 $23^{\circ} \mathrm{C} \pm 2{ }^{\circ} \mathrm{C}$, 상대습도 최대 $65 \%$ 에서 $150 \mathrm{~cd} /$ $\mathrm{m}^{2}$ 일 때, 밝기 정밀도는 $\pm 2 \% \pm 1$ digit이며, 색도 정밀도는 $\mathrm{L}_{\mathrm{v}} \mathrm{Xy}$ 좌표로 \pm 0.002 이다. CS 200 의 초점거리는 $296 \mathrm{~mm}^{\sim}$ 무한 대이기 때문에 화면의 색도를 측정할 때 $\mathrm{LCD}$ 화면과의 거리 는 $60 \mathrm{~cm}$ 로 한정하였다. 실제 측정에서는 주변 조명을 모두 끄고, 모든 빛을 차단한 후에 실시하였다.

분광측색계를 사용하여 투과된 필름 오버레이의 $\mathrm{Lu}^{\prime} \mathrm{v}^{\prime}$ 좌 표를 Fig. 5에, 엑스페리아 아크 스마트폰과 갤력시탭 10.1에 대하여 색도계를 사용하여 측정된 가상 색오버레이의 $\mathrm{Lu}^{\prime} \mathrm{v}^{\prime}$ 좌표를 Fig. 6과 Fig. 7에 각각 표시하였다. 그림에 나타난 번호는 각 오버레이 샘플의 번호이며, 1-10은 단일색, 11-20 는 단일 중첩색, 21-29는 인접 중첩색 번호이다. 갤럭시 탭 10.1 은 백색 배경이 약한 연보라 색을 띠며, 화면밝기는 백 색 배경에서 $394 \mathrm{~cd} / \mathrm{m}^{2}$ 으로, 엑스페리아 아크의 $359 \mathrm{~cd} / \mathrm{m}^{2}$ 보 다 밝았다. 전체적으로 갤럭시탭의 경우가 회색을 중심으로 엑스페리아 아크보다 측정좌표들의 값들이 더 넓게 퍼진 것 을 확인할 수 있었고, $\mathrm{v}^{\prime}$ 값들이 더 작게 측정되었다.

색도의 차이는 밝기 값을 제외한 $\mathrm{CIE} \mathrm{Lu}^{\prime} \mathrm{v}^{\prime}$ 좌표값의 차 이인 $\Delta \mathrm{u}^{\prime}, \Delta \mathrm{v}^{\prime}$ 이며, 이 값을 식 (5)에 대입하여 차이 값의 전체 크기 $\left(\Delta \mathrm{Eu}^{\prime} \mathrm{v}^{\prime}\right)$ 를 산출하였다. 각 기기별로 29 개 오버레 이 샘플에 대하여 산출된 $\Delta \mathrm{Eu}^{\prime} \mathrm{v}^{\prime}$ 값을 Fig. 8과 Fig. 9에 표 시하였다. 엑스페리아 아크의 경우 대부분의 오버레이에서 


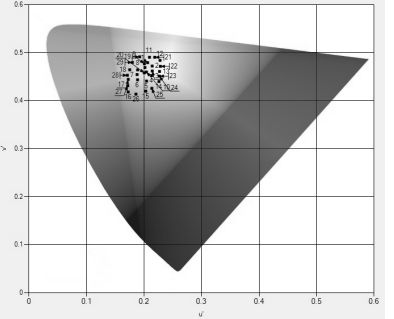

Fig. 5. Measurement results of Overlays u'v' chromaticity of Intuitive

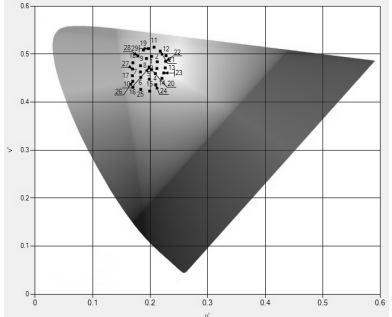

Fig. 6. Measurement results of u'v' chromaticity of Virtual Overlays with white background in Xperia Arc

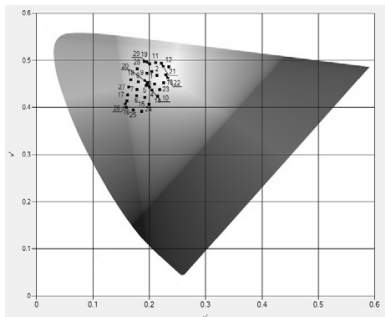

Fig. 7. Measurement results of u'v' chromaticity of Virtual Overlays with white background in Galaxy Tab 10.1

0.015 이하의 차이가 나고, 인근 중첩색에서만 주로 큰 차이 가 발생한 반면 갤럭시탭의 경우는 핑크와 보라색, 그 색들 이 섞인 오버레이들에서 주로 큰 차이를 보였다. 갤럭시 탭 의 디스플레이는 OLED를 사용하여 백색 배경이 연보라색 을 띠는 것과 깊은 관련이 있는 것으로 추정된다. 실제 필 름 오버레이와 가상 색 오버레이와의 색 차이 $\left(\Delta \mathrm{Eu}^{\prime} \mathrm{v}^{\prime}\right)$ 의 평 균과 표준오차는 소니사의 엑스페리아 아크의 경우 각각 $0.02188,0.006265$ 이며, 갤럭시탭의 경우에는 각각 0.022575 와 0.006654 로 색상의 차이를 시각적으로 분명히 구별할 만큼 오차가 크지 않았다. 실제 CM3600d의 색채치 재현성은 표 준편차가 $\Delta \mathrm{E} * \mathrm{ab}$ 기준으로 0.02 이며, 색도계 $\mathrm{CS}-200$ 의 색도 정밀도는 Lvxy좌표로 \pm 0.002 이다. 따라서 측정된 차이는 무 시할만할 수준이다.

$$
\Delta E u^{\prime} v^{\prime}=\sqrt{\Delta u^{\prime 2}+\Delta v^{\prime 2}}
$$

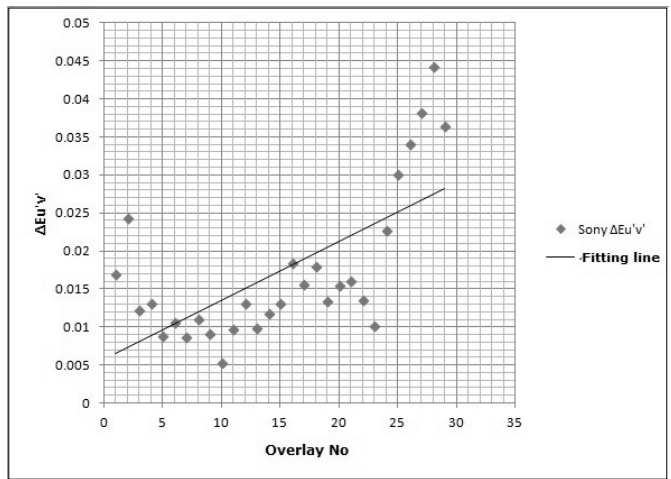

Fig. 8. Difference of chromaticity between Virtual Overlays and Intuitive Overlays in Xperia Arc

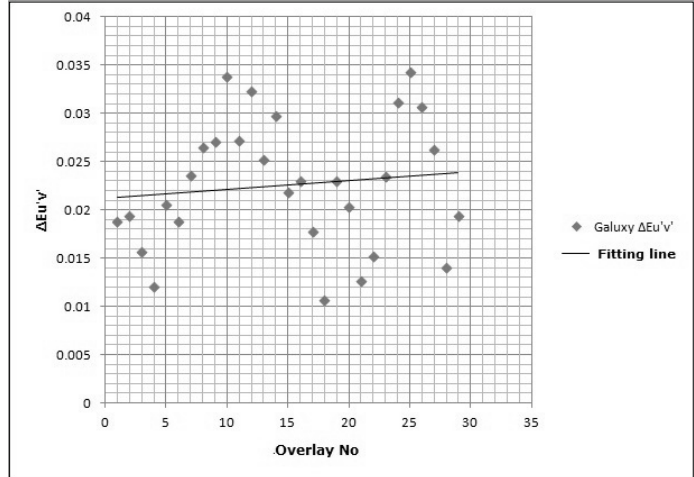

Fig. 9. Difference of chromaticity between Virtual Overlays and Intuitive Overlays in Galaxy Tab 10.1

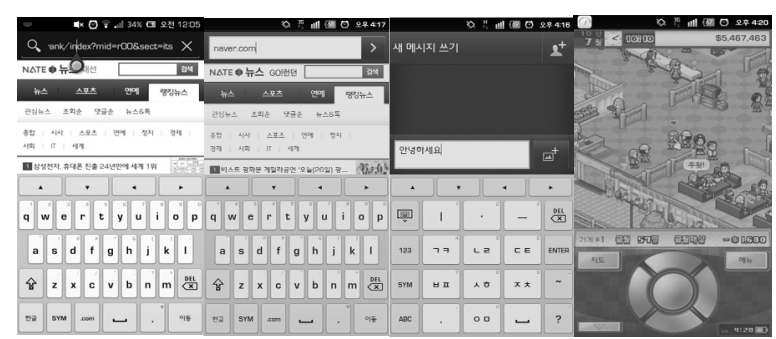

(a)

(b)

(c)

(d)

(a) : web browser sample without Virtual Overlays

(b) : web browser sample

(c) : text message sample

(d) : graphic game sample

Fig. 10. Application samples of Virtual Overlays

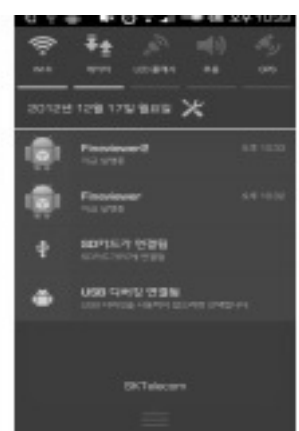

Fig. 11. Status screen of Fineviewer App. using foreground service (yellow) and Fineviewer2 App. using foreground service(orange)

구현된 가상 색 오버레이 앱을 스마트 폰에 적용한 예를 Fig. 10에 표시하였다. 오버레이가 백그라운로 작동하여, 현 재 작동시키는 앱에 전혀 영향을 미치지 않고 작동하였다. 다른 앱이 스마트 폰이나 태블릿 $\mathrm{PC}$ 에서 사용될 때, 가상 색 오버레이와의 서비스 충돌이나 서비스의 종료를 방지하 기 위하여 가상 색 오버레이를 포그라운드 서비스로 구현하 여 시험하였다. 가상 색 오버레이 애플리케이션을 두 개로 만들어 구동시키고, 하나의 앱에서는 오렌지색 오버레이를, 다른 앱에서는 노란색 오버레이를 선택하게 하였다. 두 애 
플리케이션은 모두 Fig. 11의 Fineviewer와 Fineviewer2와 같이 중지 없이 동작하였다. 그러나 스크린의 최상위 윈도 우를 두 앱이 모두 사용하므로 화면에서는 노란색과 오렌 지 색이 중첩되어 나타났다. 따라서 다른 앱에서 스크린의 최상위 윈도우를 사용하는 경우, 가상 색 오버레이와 중첩 된 스크린을 보게 될 것이다.

\section{5. 결 론}

본 연구에서는 안드로이드 운영체계를 사용하는 스마트 폰이나 태블릿 $\mathrm{PC}$ 에서 사용할 수 있는 가상 색 오버레이 앱을 구현하였다. 이 앱은 한국형 웹 접근성 지침 2.0과 모 바일 애플리케이션 접근성 지침에서 규정한 광과민성 발작 과 같은 광과민성 증후군의 증세를 완화시키거나 제거하는 데 효과가 있다. 자세한 색 표현을 위하여 기존의 필름 오 버레이에서 사용되는 단일 색, 단일 색 중첩, 인접 색 중첩 을 모두 구현하였다. 가상 오버레이의 정확한 원 색도와 알 파 값을 결정하기 위하여 분광측색계를 사용하여 기존의 필 름 오버레이인 Intuitive Overlays의 색 정보와 투과율을 측 정하고, 투과율과 알파 값의 관계 설정을 통하여 가상 색 오버레이에 적용할 알파 값을 추정하고, 색 변환과 비선형 색 지정을 통하여 오버레이의 원 색도를 결정하여 가상 색 오버레이를 구현하였다. 색도계를 사용하여 스마트폰과 태 블릿 $\mathrm{PC}$ 의 디스플레이에서 가상 오버레이의 색도를 측정한 결과 필름 오버레이를 사용한 경우와 거의 일치하였다. 구 현한 가상 색 오버레이를 문자메시지 작성창, 웹 브라우저, 그래픽 객체를 포함한 게임 등에 적용하여 잘 동작함을 확 인하였다. 다만 동영상의 경우에는 작동되지 않았다.

구현된 오버레이는 컴퓨터 게임과 같이 그래픽 객체를 마 우스로 조작하는 응용프로그램에 사용될 수 있으며, 전자상 거래와 같은 텍스트 입력, 리스트 박스 선택과 버튼 제어가 복잡하게 결합된 웹 브라우저 응용 환경에서 사용하기가 편 리하며, WRRT의 시험 결과로 선택된 색을 직접적으로 사 용할 수 있다.

\section{참 고 문 헌}

[1] Korean Web Content Accessibility Guidelines 2.0, Korean Telecommunication Technology Association, 2009.
[2] Mobile Application Accessibility Guidelines, MOPAS proclamation No.2011-38, Korean Ministry of Public Administration and Security, 2011.

[3] Eric Emerson Schmidt, Chairman of Google "Speed, study Korea”, Korea Joonang Daily 2012, 2, 21.

[4] Mears, O. 1980. "Figure/ground, brightness, contrast \& reading disabilities". Visible Language, 14, 13-29.

[5] Irlen, H. 1983. "Successful treatment of Learning Disabilities", 1st Annual Convention of the American Psychological Association, Anaheim California.

[6] Young Mi Kim, Hyung Bae Park, Ki Choong Mah, "Survey of the Attention Deficit, Hyperactivity Disorder and Visual Perception in Students who Live in Daejeon city", Korean Journal of Vision Science, 8(1): pp.85-99, 2006.

[7] Virtual Reading Ruler, http://www.crossboweducation.com/

[8] Seung Hwan Park, Hoon Il Choi, Young Gun Jang, "An Implementation of Virtual Colored Overlay to Reduce Visual Information Processing Deficit", Journal of Rehabilitation Research, Vol.12, No.1, pp.138-159, 2008. 4.

[9] Arnold Wilkins, 'Reading Through Colour', John Wiley \& Sons Ltd., 2003.

[10] Intuitive overlays dispensing packs, http://www.ioosales. co.uk/html/practice/eye05E.html, 2012.

[11] Color conversion math and formulas, http://www. easyrgb.com/index.php?X=MATH

[12] Ed Burnette, 'Hello, Android: Introducing Google's Mobile Development Platform', 1st Edition, Pragmatic Bookshelf, 2009.

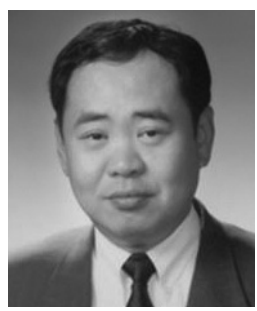

장 영 건

e-mail :ygjang@cju.ac.kr 1980년 인하대학교 전자공학과(학사) 1991년 인하대학교 전자공학과(석사) 1995년 인하대학교 전자공학과(박사) 1980년 1982년 국방과학연구소 연구원 1983년 1994년 대우중공업 중앙연구소 책임연구원

1995년 고등기술연구원 책임연구원

1996년 현 재 청주대학교 컴퓨터정보공학과 교수 관심분야: 지능형 웹 시스템, 보조공학, 지능형 로봇 